\begin{tabular}{|c|c|c|}
\hline $\bar{J}$ & International Journal of Current Research in & \\
\hline & Biosciences and Plant Biology & $\div 37^{\circ}$ \\
\hline $\begin{array}{l}\text { EXCELLENT } \\
\text { PUBLISHERS } \\
\end{array}$ & $\begin{array}{c}\text { ISSN: 2349-8080 (Online) • Volume } 3 \bullet \text { Number } 5 \text { (May-2016) } \\
\text { Journal homepage: www.ijcrbp.com }\end{array}$ & \\
\hline
\end{tabular}

\title{
DNA Barcoding of Highly Threatened Sacred Plant - Aegle marmelos L.
}

\author{
D. Sivalingam*, R. Rajendran and K. Anbarasan \\ Department of Botany, Annamalai University, Annamalai Nagar-608 oo2, Tamil Nadu, India \\ *Corresponding author.
}

\begin{tabular}{|c|c|}
\hline Abstract & Article Info \\
\hline $\begin{array}{l}\text { DNA barcoding is a useful tool to define operational taxonomic units based on } \\
\text { standardized DNA regions. In this study, the matK chloroplast gene was tested for } \\
\text { species identification of highly threatened sacred plant Aegle marmelos L., to document }\end{array}$ & $\begin{array}{l}\text { Accepted: } 23 \text { April } 2016 \\
\text { Available Online: } 06 \text { May } 2016\end{array}$ \\
\hline $\begin{array}{l}\text { their reliable identification, discrimination, similarities and evolutionary trend with their } \\
\text { related taxa for future use. DNA isolation from leaf sample of Aegle marmelos was }\end{array}$ & Keywords \\
\hline $\begin{array}{l}\text { carried out by using a modified Cetyl Trimethyl Ammonium Bromide method (CTAB). } \\
\text { Gradient PCR amplification was performed for the isolated DNA using matK gene and } \\
\text { the primers, matK472F and matK1248R. Pairwise sequence alignments were made with } \\
\text { BLAST and multiple sequence alignments were also made with ClustalW. Based on the } \\
\text { sequence alignments, dendrograms were constructed using the software, Mega } 5 \text { and } \\
\text { Neighbor Joining tree method was used to study the phylogenetic aspects of the species } \\
\text { studied and with their related taxa. The success rate of PCR amplification was } 90-95 \% \\
\text { and the success rate of DNA sequence was } 95 \% \text {. The maximum identity of the present } \\
\text { study sample was } 100 \% \text { with Aegle marmelos and the similarity of other related species, } \\
\text { Severinia buxifolia, Citrus trifoliata and Citrus reticulata was } 97 \% \text { respectively. }\end{array}$ & $\begin{array}{l}\text { Aegle marmelos } \mathrm{L} \text {. } \\
\text { matK472F } \\
\text { matK1248R primer } \\
\text { Sacred plant } \\
\text { Threatened species }\end{array}$ \\
\hline
\end{tabular}

\section{Introduction}

DNA barcoding, a new approach for species identification using a short, standardized DNA region, became an important tool in distinguishing species, discovering cryptic species, protecting endangered species and identifying traditional medicinal (TM) values of highly threatened sacred plants (Hebert et al., 2003; Kress et al., 2005; Hajibabaei et al., 2007; Chen et al., 2010; China Plant BOL Group, 2011; Li et al., 2011a). For animal DNA barcoding, the mitochondrial gene Cytochrome-C Oxidase subunit 1 (CO1) shows extremely great efficiency. However, the marker is faced with serious challenge in plant due to its low substitution rates in plant mitochondrial genome (Kress et al., 2005; Hollingsworth et al., 2011). In recent years, experts paid attention to DNA markers from the chloroplast and nuclear genome, and they did a lot of work on screening and testing for potential DNA barcodes (China Plant BOL Group, 2011; Hollingsworth et al., 2011; Dong et al., 2012). An ideal DNA barcode should be universal, reliable and cost-effective and have good discriminatory power (CBOL Plant Working Group, 2009). But none of the potential DNA regions could meet these criteria. As a result, multiple markers become inevitable choice for DNA barcoding in plant. Combination of potential regions is being debated and controversial until now (Hollingsworth et al., 2011).

The CBOL-PWG promoted a multi-locus solution comprising portions of the plastid gene $r b c \mathrm{~L}$ and $m a t \mathrm{~K}$ as core barcode gene for identification of land plants, for attaining the $70-75 \%$ discrimination to the species level (Ferri et al., 2015). CBOL Plant Working Group recommended a two-marker combination of chloroplast gene $r b c \mathrm{~L}$ and mat $\mathrm{K}$ as the core plant barcode. As 
previously reported $r b c \mathrm{~L}$ routinely produced high quality bi-directional reads, but had a lower discriminating power as matK (Carrier et al., 2013). Subsequently, Chinese Botanists made a great deal of researches and proposed ITS/ ITS2 as one of the core DNA barcodes (China Plant BOL Group, 2011; Yao et al., 2010; Li et al., 2011b), although the nuclear marker was still questioned for its disadvantages in some special taxon such as gymnosperms (China Plant BOL Group, 2011; Kiss, 2012).

In forensic botany, the identification of plant species is the first step. The forensic botanist requires DNA extraction, amplification and sequencing. The information generated from plant DNA databases can be used to correlate specific markers with known plant species to establish forensic linkage using sequence similarity and homology search tools, so we suggest two barcoding markers for plant molecular systematic investigations at the species level by universal primers amplifications. A molecular DNA-based identification, like a traditional morphological taxonomic key, provides criteria that progressively identify an unknown plant sample to a taxonomic rank (Ferri et al., 2008).

Sacred trees (Sthalavrikshas) have a unique place in the fabric of Indian heritage. These trees symbolize knowledge and spirituality. In ancient times, the trees were worshipped along with Gods and established in the temples as Sthalavrikshas, i.e., trees associated with the deity in the temple and become an inseparable part of the faith. Such trees were guarded and their saplings from mother plants were given to other temples.

Sthalavrikshas are valued for their botanical, medicinal, environmental, religious and mythical importance. The Sthalavrikshas constitute a part of genetic resources for the conservation of species diversity. Propagation of Sthalavrikshas in temples contributes to the conservation of our floral diversity. Medicinal parts of the Sacred trees (Sthalavrikshas) are used in different forms. It is given in the form of paste, juice, dried powder and made into tablets and juices mixed with sugar and honey to cure various diseases (Ranjan, 1996; Amirthalingam, 1988; Jain, 2004).

The degradation of forests and destruction of habitat due to anthropogenic activities are the major causes of decline in the global biodiversity (Bhakat and Pandi, 2003 and 2007). Various indigenous communities all over the world lived in harmony with nature and thus conserved biodiversity (Jeeva and Sukumaran, 2008;
Silja et al., 2008; Singh, 2008; Malhotra et al., 2001). Many traditional conservation practices of indigenous people in many parts of the world such as small forest patches by dedicating them to the local deity, contributed to the conservation and protection of biodiversity. Sacred plants protected by the local people through religious and cultural practices evolved to minimize destruction. Sacred plants are important not only for their botanical, economical, environmental, religious, medicinal and mythical values but also forms an important biological heritage of our nation and play role in the conservation of environment and biodiversity (Umavathi and Parvathi, 2012). Now-a-days, Aegle marmelos is highly threatened in various places of Tamil Nadu, India (Balagengatharathilagam et al., 2012; Sivakamasundari et al., 2015). The present study would be beneficial to evaluate the efficiency of the potential DNA barcodes in Aegle marmelos.

\section{Materials and methods}

\section{Plant materials}

The leaf sample of Aegle marmelos used in this study was collected from Sri Villeeswarar Temple - Idikarai, Coimbatore, Tamil Nadu, India (Fig. 1). The voucher specimens were identified and deposited in the Herbarium of Department of Botany, Annamalai University, Chidambaram, Tamil Nadu, India. Some saplings of sacred plants were planted in Botanical Garden, Department of Botany, Annamalai University as a conservative measure of this highly threatened sacred plant species.

\section{DNA extraction, amplification and sequencing}

Total DNA was extracted from young leaves using modified CTAB method (Doyle and Doyel, 1987). Gradient PCR was performed using isolated genomic DNA to determine the optimum annealing temperatures of the Primers used, namely matK 472F (5'-CCC RTY CAT CTG GAA ATC TTG GTT C-3') and matK 1248R (5'-GCT RTR ATA ATG AGA AAG ATT TCT GC-3'). This primer was obtained from Genei, Bangalore, India. The PCR reaction mixture was consisted of $10 \mathrm{x}$ Taq buffer, dNTP mix $100 \mathrm{mM}$, Taq polymerase $(3 \mathrm{U} / \mu \mathrm{l})$ and 5-50 ng of template DNA.

Thermal cycling conditions for gradient PCR were as follows: Initial DNA denaturation at $94^{\circ} \mathrm{C}$ for $3 \mathrm{~min}$, followed by 40 cycles of final DNA denaturation at $94^{\circ} \mathrm{C}$ for $30 \mathrm{~s}$, primer annealing temperature at $48-52^{\circ} \mathrm{C}$ for 
$40 \mathrm{~s}$, DNA strand extension at $72^{\circ} \mathrm{C}$ for $1 \mathrm{~min}$, and final extension at $72^{\circ} \mathrm{C}$ for $10 \mathrm{~min}$. The PCR products were verified by electrophoresis in $1 \%$ agarose gel stained with ethidium bromide. Bidirectional sequencing was conducted by ABI 3730 DNA sequencer (Applied Biosystems, Foster City, CA, USA). Sequences with poor pink graph were progressed by repeated sequencing or discarded in final analysis.
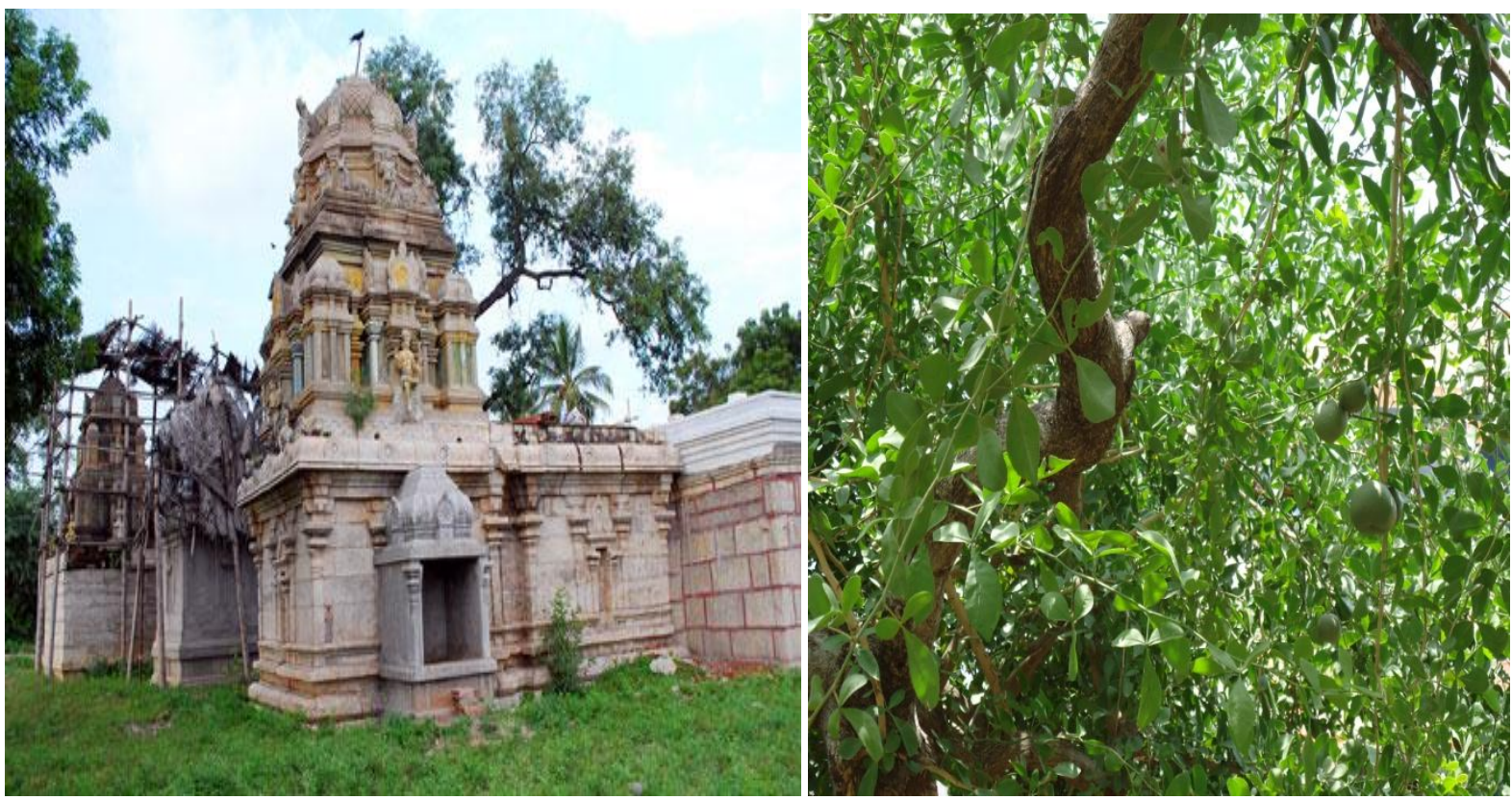

Fig. 1: Sri Villeeswarar Temple, Idikarai (Coimbatore) and Sthalavriksham - Aegle marmelos L.

\section{Data analysis}

The DNA sequences were assembled and edited with SeqMan (DNA STAR package; DNAStar Inc., Madison, WI, USA). To verify whether the candidate barcodes were competent for family or genus assignment in authenticating Aegle marmelos, mat $\mathrm{K}$ sequences of the different genera of the family Rutaceae were downloaded from GenBank for analysis. Sequences of plant sample were aligned with those from GenBank by ClustalW (Thompson et al., 1997) software, and the genetic distances were calculated using the Kimura-2-Parameter (K-2-P) model. The phylogenetic analysis based on the $m a t \mathrm{~K}$ regions was performed by MEGA 5.0 (Kimura, 1980; Tamura et al., 2011) using the Neighbor Joining (NJ) method. Bootstrap support (BS) values for individual clades were calculated by running 1000 bootstrap replicates of the data.

\section{Results}

\section{Genomic DNA extraction}

Genomic DNA was successfully extracted from Aegle marmelos (without liquid nitrogen-modified CTAB method).

\section{PCR and sequencing success}

The primers for the DNA barcode were universally applicable to the studied species. The success rate of Gradient PCR amplification for matK was $90-95 \%$. The amplification of Gradient PCR product was strong enough for isolation of bands or direct sequencing and in the present study, the DNA sequences were done at Xcelris Labs Ltd., Sydney House, Premchand Nagar Road, Bodakdev, Ahmadabad - 380 054, India. The methods of $\mathrm{ABI}-3730 \mathrm{Xl}$ sequencer gave a success rate of $90-95 \%$ and read length of 700 bases or more.

\section{Sequence analysis and retrieval}

The sequence alignment was performed between genuine and adulterant samples to observe the sequence variations for their discrimination to each other. The matK sequences of Aegle marmelos were obtained using the Basic Local Alignment Search Tool (BLAST) through http://blast.ncbi.nlm.nih.gov/Blast.cgi to confirm the present study sequences from related genus or species sequences available on NCBI database. The results obtained are shown in different figures (Figs. 2-5). The sequences were analyzed using BLAST for pairwise sequence alignment (Fig. 2) and used ClustalW for the 
multiple sequence alignment (Fig. 3). The quality of nucleotide sequence of Aegle marmelos are shown in different colours in Fig. 4a - 4c. Blue colour denoted good quality of nucleotide. Starting and ending nucleotides are in yellow and red colours, which showed low quality nucleotides. The BLAST was also used for the identification of species with matK gene (Tables 1 and 2). After the multiple sequence alignment, the phylogenetic tree was constructed using MEGA 5 Version (Neighbor Joining Tree).

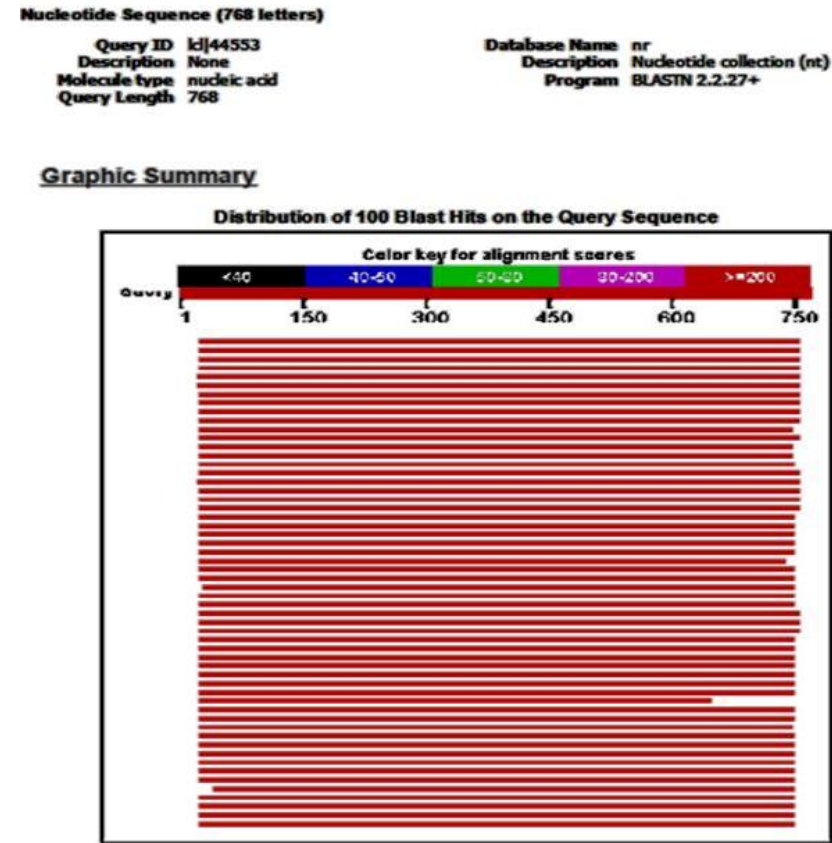

Fig. 2: BLAST formatting results of Aegle marmelos (sample).

\begin{abstract}
HM163957 FJ716731 JQ589068 HE967463 Sample

AATCCATCCTCTITTTTCTCTGTAACCAATCGTCTCATTTACAATCAACATCCTCTCGAG AATCCATCCTCTTITTTCTCTGIAACCAATCGTCTCATTTACAATCAACATCCTCTCGAG AATCCATCCTCTITITTCTCTGIAACCAATCGTCTCATTTACAATCAACATCCTITCGAG AATCCATCCTCTITTTTCTCTGTAACCAATCGTCTCATTTACAATCAACATCCTITCGAG AATCCATCCTCTTTTTTCTCTGTAACCAATCGTCTCATTTACAATCAACATCCTCTCGAG

HM163957 FJ716731 JQ589068 HE967463 Sample

TCCTCGTTGAGCGAACGTATTTCTATGGAAAAGTCGAATATCTTGTCGAAGTCTITGCTA TCCTCGITGAGCGAACGTATTTCTATGGAAAAGTCGAACATCTTGTCGAAGTITTTGCTA TCCTCGIIGAGCGAACGIATITCTATGGAAAAGCGAACATCTIGICGAAGITITIGCTA TCCTCGITGAGCGAACGIATTTCTATGGAAAAGTCGAACATCTTGTCGAAGTCTTTGCTA TCCTCGTTGAGCGAACGTATTTCTATGGAAAAGTCGAATATCTTGTCGAAGTCTITGCTA

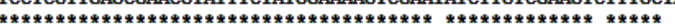

HM163957 FJ716731 AAGATTTTCAGGACATCTTAGGGTTGITCAAGGATCCTITCATGCATTATGTIAGATATC AAGATTTTCAGGACATCTTAGGGTTGITCAAGGATCCTITCATGCATTATGTTAGATATC AAGATTTTCAGGACATCTTAGGGTTGGTCAAGGATCCTITCATGCATTATGTIAGATATC AAGATTTTCAGGACATCTTAGGGTTGGTCAAGGATCCTTTCATGCATTATGTTAGATATC AAGATTTTCAGGACATCTIAGGGTTGGTCATCTAGGGTITAAGGATCCTTTCATGCATTATGTTAGATATC AAGATTTCAGGACATCTIAGGGTTITCAAGGATCCTTCATGCATTATGTIAGATATC

HE967463

Sample

AAGGAAAATCCATTTTGGCTTCAAAGGATACGCCTCTTCTGATGAATAAATGGAAATATI AAGGAAAAGCCATTTTGGCTTCAAAGGATACGCCTCTTCTGATGAATAAATGGAAATAT AAGGAAAATCCATTTTGGCTTCAAAGGATACGCCTCTTCTGATGAATAAATGGAAATATI AAGGAAAATCCATTTTGGCTTCAAAGGATACGCCTCTTCTGATGAATAAATGGAAATATT AAGGAAATTCCATTTTCGCTTCAAAGCATACCCCTCTTCTCATCATTAATCCAMATATT AAGGAAAATCCATTITGGCTICAAAGGATACGCCTCTICTGATGAATAAATGGAAATAT

ACCTTGTCGGTTIATGGCAATGGCATTTTCACGTGTCTTCTCAACCAGGAAGGGTTCAGC ACCTTGTCGGTTIATGGCAATGGCATTTTCACGTGTCGTCTCAACCAGGAAGGGTTCAGC ACCTTGTCGGTTIATGGCAATGGCATITTCACGCGICTTCTCAACCAGGAAGGGTTCAGC ACCTTGTCGGTTTATGGCAATGGCATTTTCACGCGTCTTCTCAACCAGGAAGGGTTCAGC ACCTTGTCGTTITATGGCAATGGCATTTCACGTGTCTTCTCAACCAGGAAGGTTCAGC JQ58906 HE96746
\end{abstract}

Fig. 3: Multiple sequence alignment of sample (Aegle marmelos) using ClustalW method.

SING:7 A:9 T:8 C:7
KB.bcp
KB 1.4.0
Cap:8

Fig. 4a: DNA sequences of Aegle marmelos (sample). 


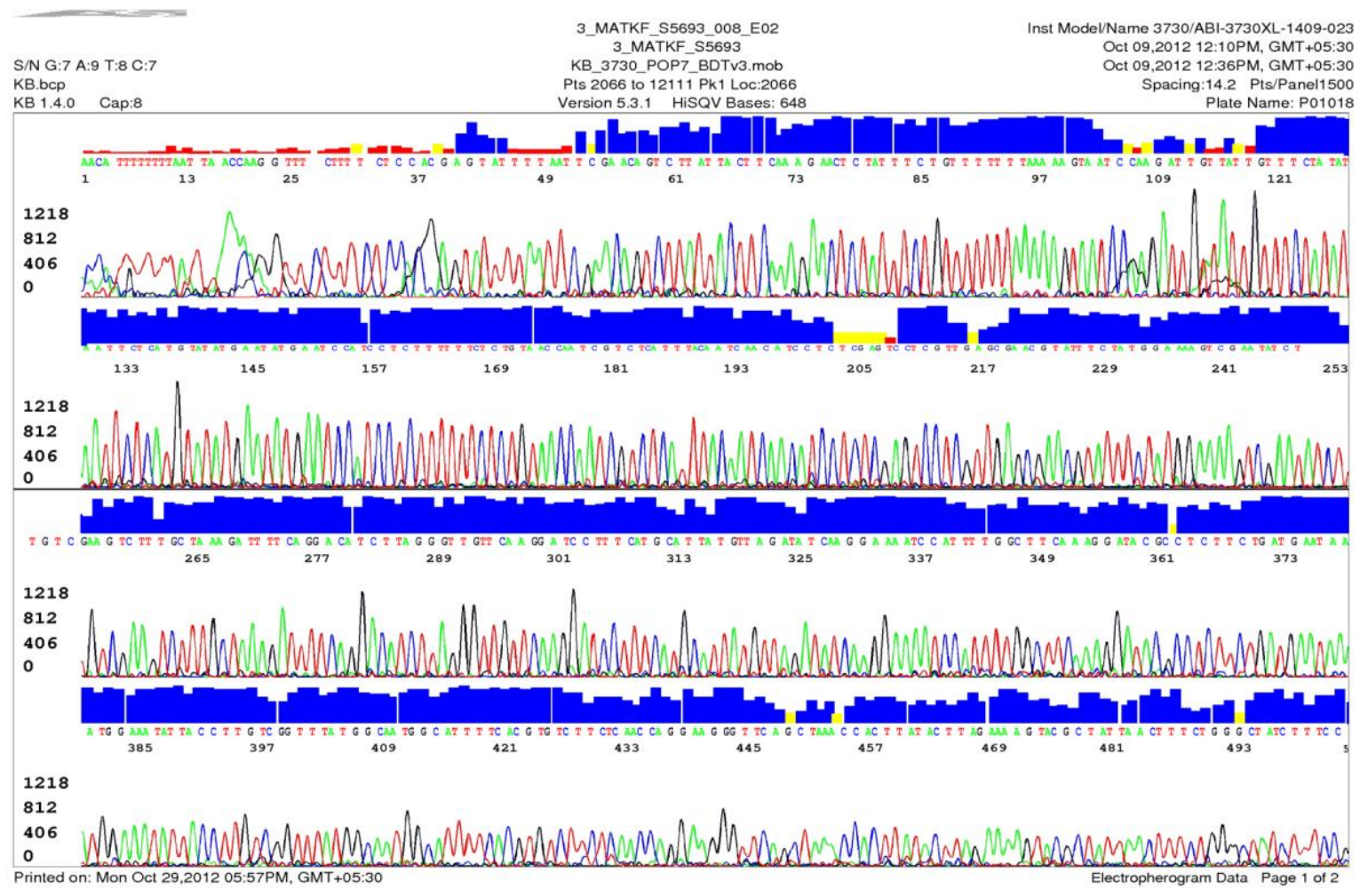

Fig. 4b: Electropherogram of Aegle marmelos (sample).

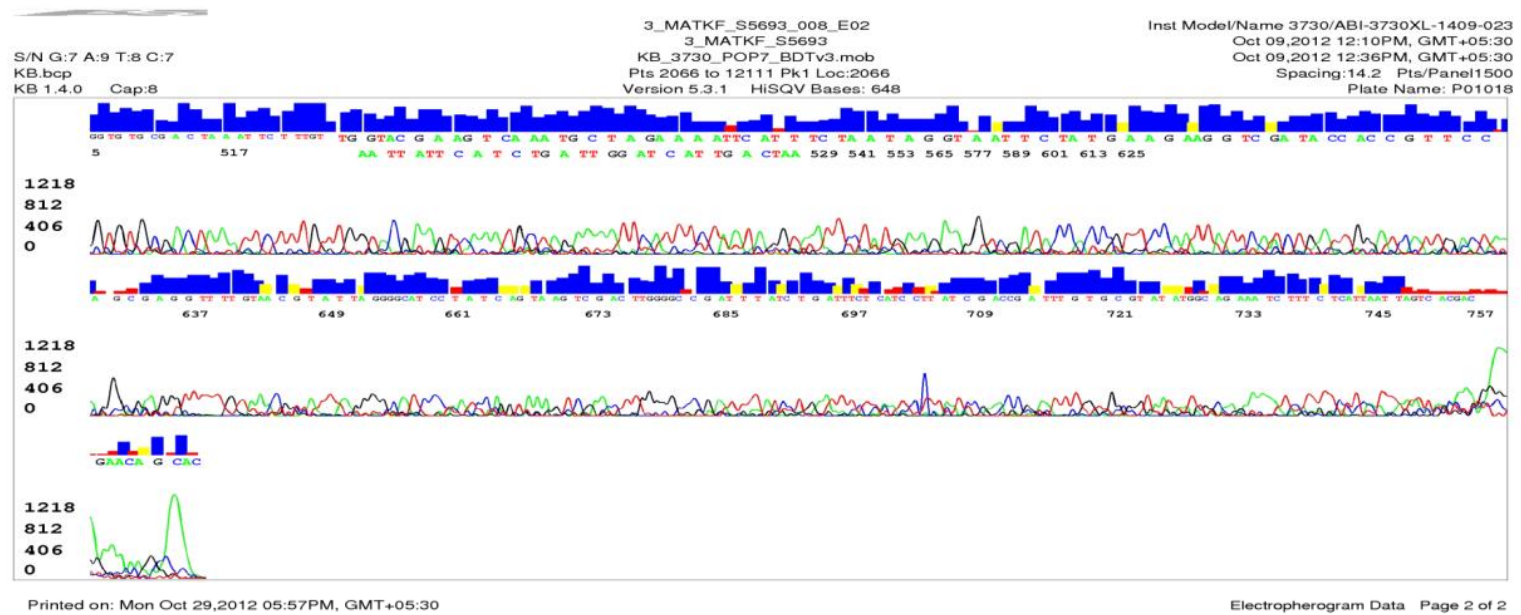

Fig. 4c: Electropherogram data of Aegle marmelos (sample).

Table 1. BLAST identification of sample (Aegle marmelos)

\begin{tabular}{llll}
\hline Accession no. & Accession description & E-value & Max. identity \\
\hline HM163957 & $\begin{array}{l}\text { Aegle marmelos voucher K:Chase 1340 maturase K (matK) gene, } \\
\text { complete cds; chloroplast }\end{array}$ & 0.0 & $100 \%$ \\
FJ16731 & $\begin{array}{l}\text { Severinia buxifolia maturase K (matK) gene, complete cds; } \\
\text { chloroplast }\end{array}$ & 0.0 & $97 \%$ \\
HE967463 & $\begin{array}{l}\text { Citrus trifoliata } \text { chloroplast partial matK gene for maturase K, } \\
\text { specimen voucher MIB:ZPL:04007 } \\
\text { JQ589068 }\end{array}$ & 0.0 & $97 \%$ \\
Citrus reticulata voucher BioBot06153 maturase K (matK) gene, & 0.0 & $97 \%$ \\
\hline
\end{tabular}


Table 2. The sequences retrieved from NCBI - gene bank for the study.

\begin{tabular}{llll}
\hline S. No. & Accession no. & Species & Reference \\
\hline 1 & HM163957 & Aegle marmelos & Salvo et al. (2011) \\
2 & FJ716731 & Severinia buxifolia & Salvo et al. (2010) \\
3 & HE967463 & Citrus trifoliata & Bruni et al. (2012) \\
4 & JQ589068 & Citrus reticulata & iBOL (2012) \\
\hline
\end{tabular}

\section{Phylogenetic tree}

DNA barcoding is a new diagnostic technique in which species identification is performed using DNA sequences from a short and standardized DNA region of the genome; it has become the trend and hot spot of biology systematics and identification in recent years (Chen et al., 2009 and 2010). Phylogenetic study was performed using the molecular evolutionary genetics analysis (MEGA) 5.0 software in accordance with the Kimura 2-Parameter (K2P) model. The phylogenetic tree for the present study was constructed using the Neighbor Joining (NJ) method (Fig. 5).

\section{Aegle marmelos $\mathrm{L}$.}

In the present study, the plant sample showed $100 \%$ similarity with Aegle marmelos in phylogenetic analysis. Other species involved in the present are Citrus reticulata, Citrus trifoliata and Severnia buxifolia. All these species were belonged to the Rutaceae family (Fig. 5).

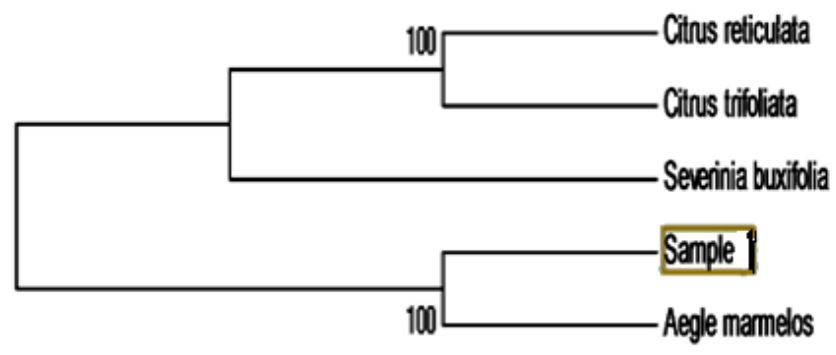

Fig. 5: Phylogenic tree represents the evolutionary relationship between the plant species and sample (Aegle marmelos).

\section{Discussion}

Sthalavrikshas (Sacred plants) are venerated from time immemorial by devotees as being as holy as the presiding deity of a temple (Gunasekaran and Balasubramanian, 2005). Very few field studies have been conducted on Sthalavriksha practice and its role in social, ecological and environmental impacts of local people. In particular, ethnomedicinal uses on Sthalavrikshas, occurring in the temples of Tamil Nadu have been unexplored (Tholkappiyavathi and Nadanakunjidam, 2013). Considering the importance of Sthalavrikshas, the present study has been undertaken.

DNA barcoding is a new technique and is accepted global level for species identification. However, a great deal of effort is still needed before DNA barcoding of plants can be considered sufficiently reliable for widespread practical application. The strategy for barcode development should be reached as soon as possible. A desirable DNA barcode must simultaneously possess enough sequence variations for species identification and adequate conserved flanking sites for the designation of the universal primers (Stoeckle, 2003). Recent candidate barcodes are $m a t \mathrm{~K}, y c f 5, r p o \mathrm{C} 1, r b c \mathrm{~L}$ and $p s b \mathrm{~A}-t r n \mathrm{H}$ in the chloroplast genome, as well as ITS and ITS2 from the nuclear ribosomal DNA (Kress et al., 2005; Kress and Erickson, 2007). The matK gene is one of the most rapidly evolving plastid coding regions and it has been studied widely (Asahina et al., 2010; Liu et al., 2013; Mahadani et al., 2013; Wong et al., 2003).

Early studies adopted a strategy of using more highly conserved $\operatorname{trn\mathrm {K}}$ regions as priming positions for fragment amplification and several internal primers for sequencing. The internal primers were typically designed for specific taxa and the universality was limited (Fazekas et al., 2008). Of the primers designed, primer pair 390F/1326R is one pair of the best, as exemplified by Lahaye et al. (2008). In the present study the amplification success was 90-95\%. There are two major hot spots for forward primers: one is represented by $390 \mathrm{~F}$ and the other by $1 \mathrm{R} \_$KIM. The matK472F falls in the second hot spot. The reverse primers were tried mainly at three positions represented by 3F_KIM, 1326R, and matK_KewR. The matK1248R happens to overlap partially with MALV $\mathrm{R} 1$. There are many possible regions of the entire matK gene that may be used as a plant barcode. It was determined that the region from 600 to $1400 \mathrm{bp}$ to be the best representative of the whole-gene sequence based on the smallest distances. Considering the conservative regions for primer design and the mononucleotide repeats, that causes sequencing problems, the final region of $m a t \mathrm{~K}$ was adjusted to contain the sequence from 472 to $1248 \mathrm{bp}$. Although matK472F + matK1248R worked reasonably 
well for the samples tested, its usefulness for all angiosperms needs to be evaluated. To avoid using too many degenerate bases, it was ignored rare base substitutions. In the present study more specific primers is designed by modifying matK $472 \mathrm{~F}$ and matK1248R according to the desired sequence. Failure of amplification can also be attributed to a low quality of template DNA. Amplification of the same samples was significantly enhanced after purifying the DNA.

The primer pair identified in the present study is able to function over a broad range of annealing temperatures (from 38 to $52^{\circ} \mathrm{C}$, or even to $60^{\circ} \mathrm{C}$ ). In the present study, suggest using an annealing temperature of $48-52^{\circ} \mathrm{C}$ for this pair of primers. However, performing an initial gradient PCR will identify the best annealing temperature before performing many amplifications. Additional optimization methods for PCR can be found in standard DNA barcoding protocols (Chase et al., 2007). The sequences obtained using the primers given are the best representatives of the whole matK region and are thus of phylogenetic value. Taking the representative together with the variability of barcoding regions into consideration will potentiate species identification using phylogenetic methods when species delimitations are problematic (Yu et al., 2011).

\section{Conclusion}

The present study revealed that $m a t \mathrm{~K}$ to be the best DNA barcode for Aegle marmelos. The mat $\mathrm{K}$ provided the best species resolution values in species assemblages. The loci yielded the highest species resolution of $100 \%$. The Gradient-PCR amplification was $90-95 \%$ and the sequencing success was $95 \%$. Pairwise sequence alignments were made with BLAST and multiple sequence alignments are made with ClustalW, and based on the sequence alignments, dendrograms were constructed using software Mega 5 and Neighbor Joining tree method (100\% of bootstrap values for identification) to study the phylogenetic aspects of Aegle marmelos and with its related taxa. The phylogentic tree showed $100 \%$ similarity of the sample with Aegle marmelos sequence. Other species which showed close similarity were Citrus reticulata, Citrus trifoliata and Severnia buxifolia of the family Rutaceae. The maximum identification of Aegle marmelos was $100 \%$ and the similarity of other related species, Severinia buxifolia, Citrus trifoliata and Citrus reticulata was $97 \%$ respectively. In the present study the $m a t \mathrm{~K}$ gene sequence information could help in correct species identification and conservation for highly threatened sacred plant of Aegle marmelos L.

\section{Conflict of interest statement}

Authors declare that they have no conflict of interest.

\section{Acknowledgement}

The authors are thankful to the Professor and Head, Department of Botany and the authorities of Annamalai University for providing all necessary facilities throughout the course of this investigation. The authors gratefully acknowledge the University Grants Commission (UGC), New Delhi, for the financial support in the form of BSR meritorious Fellowship.

\section{References}

Amirthalingam, M., 1988. Sacred Trees of Tamil Nadu. The C.P. Ramaswamy Aiyar Foundation, Chennai.

Asahina, H., Shinozaki, J., Masuda, K., Morimitsu, Y., Satake, M., 2010. Identification of medicinal Dendrobium species by phylogenetic analyses using matK and $\mathrm{rbcL}$ sequences. J. Nat. Med. 64, 133-138.

Balagengatharathilagam, P., Rajasekaran, K.M., Karuppusamy, S., 2012. Diversity and utilization of ethnomedicinal plants in the selected sacred groves of southern districts of Tamilnadu. Lif Sci. Leaflet. 12, 9761098.

Bhakat, R.K., P.K. Pandi, P.K., 2003. Role of sacred groves in conservation of medicinal plants. Indian For. 129, 224-232.

Bruni, I., De Mattia, F., Martellos, S., Galimberti, A., Savadori, P., Casiraghi, M., Nimis, P.L., Labra, M., 2012. DNA barcoding as an effective tool in improving a digital plant identification system: A case study for the area of Mt. Valerio, Trieste (NE Italy). PLoS One. 7(9), e43256.

Carrier, C., Cholette, F., Quintero, C., Fulcher, C., 2013. Potential use of DNA barcoding for the identification of tobacco seized from water pipes. Forensic Sci. Int.: Genetics. 7, 194-197.

CBOL Plant Working Group, 2009. A DNA barcode for land plants. Proc. Natl. Acad. Sci. (USA) 106, 12794-12797.

Chase, M.W., Cowan, R.S., Hollingsworth, P.M., Petersen, G., Seberg, O., Jorgsensen, T., Cameron, K.M., Carine, M., 2007. A proposal for a standardized protocol to barcode all land plants. Taxon. 56, 295-299.

Chen, S.L., Song, J.Y., Yao, H., Shi, L.C., Luo, K., Han, J.P., 2009. Strategy and key technique of identification of Chinese herbal medicine using DNA barcoding. Chin. J. Nat. Med. 7, 322-327 (in Chinese).

Chen, S.L., Yao, H., Han, J.P., Liu, C., Song, J.Y., Shi, L.C., Zhu, Y.J., Ma, X.Y., Gao, T., Pang, X.H., Luo, K., Li, Y., Li, X.W., Jia, X.C., Lin, Y.L., Leon, C., 2010. Validation of the ITS2 region as a novel DNA barcode for identifying medicinal plant species, PLoS One. 5, e8613.

China Plant BOL Group, 2011. Comparative analysis of a large dataset indicates that internal transcribed spacer 
(ITS) should be incorporated into the core barcode for seed plants. Proc. Natl. Acad. Sci. (USA). 108, 1964119646.

Dong, W.P., Liu, J., Yu, J., Wang, L., Zhou, S.L., 2012. Highly variable chloroplast markers for evaluating plant phylogeny at low taxonomic levels and for DNA barcoding. PLoS One. 7, e35071.

Doyle, J.J., Doyel, J.L., 1987. A rapid DNA isolation procedure from small quantities of fresh leaf tissue. Phytochem. Bull. 19, 11-15.

Fazekas, A.J., Burgess, K.S., Kesanakurti, P.R., Graham, S.W., Newmaster, S.G., Husband, B.C., Percy, D.M., Hajibabaei, M., Barrett, S.C., 2008. Multiple multilocus DNA barcodes from the plastid genome discriminate plant species equally well. PLoS One. 3, e2802.

Ferri, G., Alu, M., Corradini, B., Angot, A., Beduschi, G., 2008. Land plants identification in forensic botany: Multigene barcoding approach. Forensic Sci. Int.: Genetics (Suppl. Series). 1, 593-595.

Ferri, G., Corradini, B., Ferrari, F., Santunione, A.L., Palazzoli, F., Alu, M., 2015. Forensic botany II, DNA Barcode for land plants: Which markers after the international agreement? Forensic Sci. Int.: Genetics. 15, 131-136.

Gunasekaran, M., Balasubramanian, P., 2005. Sthalavriksha worship: A tool in plant conservation in Tamil Nadu. In: Proceedings of National Strategy for Conservation of Sacred Groves (Eds.: Kunhikannan, C., Singh, G.). Institute of Forest Genetics and Tree Breeding, Coimbatore, India. pp.163-166.

Hajibabaei, M., Singer, G.A.C., Hebert, P.D.N., Hickey, D.A., 2007. DNA barcoding: how it complements taxonomy, molecular phylogenetics and population genetics. Trends Genet. 23, 167-172.

Hebert, P.D.N., Cywinska, A., Ball, S.L., deWaard, J.R., 2003. Biological identifications through DNA barcodes. Proc. Royal Soc. B 270, 313-327.

Hollingsworth, P.M., Graham, S.W., Little, D.P., 2011. Choosing and using a plant DNA barcode. PLoS One. 6, e19254.

iBOL, 2012. International Barcode of Life, iBOL Data Release, PLN.

Jain, S.K., 2004. A Manual of Ethnobotany. Scientific Publishers, Jodhpur.

Jeeva, S., Sukumaran, S., 2008. A floristic study on miniatrue sacred forests at Agastheeshwaram, southern Peninsular India. Eur. Asian J. Biol. Sci. 2, 66-72.

Kimura, M., 1980. A simple method for estimating evolutionary rates of base substitutions through comparative studies of nucleotide sequences. J. Mol. Evol. 16, 111-120.

Kiss, L., 2012. Limits of nuclear ribosomal DNA internal transcribed spacer (ITS) sequences as species barcodes for fungi. Proc. Natl. Acad. Sci. (USA). 109, e1811.

Kress, W.J., Erickson, D.L., 2007. A two-locus global DNA barcode for land plants: the coding rbcL gene complements the non-coding $t r n \mathrm{H}-p s b \mathrm{~A}$ spacer region $h e$.
PLoS One. 6, e508.

Kress, W.J., Wurdack, K.J., Zimmer, E.A., Weigt, L.A., Janzen, D.H., 2005. Use of DNA barcodes to identify flowering plants. Proc. Natl. Acad. Sci. (USA) 102, 83698374.

Lahaye, R.M., Van der Bank, D., Bogarin, J., Warner, F., Pupulin, G., Gigot, O., Maurin, S., Duthoit, T.G. Barra Clough, Savolainen, V., 2008. DNA barcoding the floras of biodiversity hotspots. Proc. Nat. Acad. Sci. (USA). 105, 2923-2928.

Li, D.Z., Liu, J.Q., Chen, Z.D., Wang, H., Ge, X.J., Zhou, S.L., Gao, L.M., Fu, C.X., Chen, S.L., 2011b. Plant DNA barcoding in China. J. Syst. Evol. 49, 165-168.

Li, M., Cao, H., But, P. P.-H., Shaw, P.-C., 2011a. Identification of herbal medicinal materials using DNA barcodes. J. Syst. Evol. 49, 271-283.

Liu, Y.M., Wang, K., Liu, Z., Luo, K., Chen, S.L., Chen, K.L., 2013. Identification of medical plants of 24 Ardisia species from China using the matK genetic marker. Pharmacogn. Mag. 9, 331-337.

Mahadani, P., Sharma, G.D., Ghosh, S.K., 2013. Identification of ethnomedicinal plants (Rauvolfioideae: Apocynaceae) through DNA barcoding from northeast India. Pharmacogn. Mag. 9, 255-263.

Malhotra, K.C., Ghokhale, Y., Chatterjee, S., Srivastava, S., 2001. Cultural and Ecological Dimensions of Sacred Groves in India. Indian National Science Academy, New Delhi.

Pandit, P.K., Bhakat, R.K., 2007. Conservation of biodiversity and ethnic culture through sacred groves in Midnapore district, West Bengal, India. Indian For. 133, 323-344.

Ranjan, T.P., 1996. International Environmental Laws. APH Publishing Corporation in Association with Indian Institute of Ecology and Environment, New Delhi.

Salvo, G., Ho, S.Y., Rosenbaum, G., Ree, R., Conti, E., 2010. Tracing the temporal and spatial origins of island endemics in the Mediterranean region: a case study from the citrus family (Ruta L., Rutaceae). Syst. Biol. 59(6), 705-722.

Salvo, G., Manafzadeh, S., Ghahremaninejad, F., Tojibaev, K., Zeltner, L., Conti, E., 2011. Phylogeny, morphology and biogeography of Haplophyllum (Rutaceae), a species-rich genus of the Irano-Turanian floristic region. Taxon 60(2), 513-527.

Silja, V.P., Varma, K.S., Mohanan, K.V., 2008. Ethnomedicinal plant knowledge of the Mull kuruma tribe of Wayanad district, Kerala. Ind. J. Trad. Knowl. 7, 604612.

Singh, R.K., 2008. Implications of prior informed consent for the conservations of indigenous biological diversity of Northeast India, Ind. J. Trad. Knowl. 7, 655-665.

Sivakamasundari, K. S., Karuppusamy, S., Parthipan, R., 2015. Survey on the RET listed medicinal plants in Thadagamalai range of Kanyakumari District, Tamilnadu. J. Biodivers. Endanger. Species. 3, 151.

Stoeckle, M., 2003. Taxonomy, DNA, and the bar code of life. BioSci. 53, 796-797. 
Tamura, K., Peterson, D., Peterson, N., Stecher, G., Nei, M., Kumar, S., 2011. MEGA5: Molecular evolutionary genetics analysis using maximum likelihood, evolutionary distance, and maximum parsimony methods. Mol. Biol. Evol. 28, 2731-2739.

Tholkappiyavathi, K., Nadanakunjidam, S., 2013. A survey on sthalavrikshas in the temples of Nagapattinam environ. J. Sci. 3(2), 56-58.

Thompson, J.D., Gibson, T.J., Plewniak, F., Jeanmougin, F., Higgins, D.G., 1997. The CLUSTAL_X windows interface: flexible strategies for multiple sequence alignment aided by quality analysis tools. Nucl. Acids Res. 25, 4876-4882.

Umavathi, R., Parvathi, A., 2012. Sacred trees of temples of Tiruchirappalli, Tamilnadu - The natural and ecological heritage of India. Global J. Res. Med. Plants Indigen. Med. 1(6), 225-233.

Wong, K.L., But, P.P., Shaw, P.C., 2003. Evaluation of seven DNA barcodes for differentiating closely related medicinal Gentiana species and their adulterants. Chin. Med. 8, 16-27.

Yao, H., Song, J.Y., Liu, C., Luo, K., Han, J.P., Li, Y., Pang, X.H., Xu, H.X., Zhu, Y.J., Xiao, P.G., Chen, S.L., 2010. Use of ITS2 region as the universal DNA barcode for plants and animals. PLoS One. 5, e13102.

Yu, W.-B., Huang, P.-H., Ree, R.H., Liu, M.-L., Li, D.-Z., Wang, H., 2011. DNA barcoding of Pedicularis L. (Orobanchaceae): Evaluating four universal barcode loci in a large and hemiparasitic genus. J. Syst. Evol. 49, 425437.

\section{How to cite this article:}

Sivalingam, D., Rajendran, R., Anbarasan, K., 2016. DNA barcoding of highly threatened sacred plant - Aegle marmelos L. Int. J. Curr. Res. Biosci. Plant Biol. 3(5), 88-96.

doi: http://dx.doi.org/10.20546/ijcrbp.2016.305.014 